\title{
A Study on Some Poems by Licio Gelli
}

\author{
Carlo Artemi \\ Retired worker of Department of Public Instruction, Italy
}

\begin{abstract}
This article is an analysis of some poems by Licio Gelli. Gelli has been an Italian poet but overall one of the most important and discussed protagonist of the most obscure events in Italian chronicle of the last dozen years. Author has read several poems by Gelli analyzing overall the recurrence of certain terms besides the topics of poems and the main features of language used. It's been tried to understand the psychology of poet and to find eventual links between his poetics and his public life. Results, also if preliminary, have been interesting and showing a tuning between certain features of public Gelli, as emerged by inquires, and his poetics. There are however some not obvious aspect of Gelli psychology emerging from this analysis. And these results could make light on aspects of Gelli political action.
\end{abstract}

Keywords: Italian contemporary history, atypical poets, Licio Gelli, P2 lodge, Italian scandals. Mysteries of Italy

\section{Introduction}

The phrase "Mysteries of Italy" indicates a series of events of news items never completely clarified happened in Italy from 1954 to the 90s. Events such as the kidnapping and murder of Aldo Moro, the Borghese coup,[1] the Bologna slaughter with 80 dead, the attacks of the so-called "strategy of tension " Licio Gelli has been one of the greatest protagonists of these events . An ambiguous, contradictory and unclear character. A man who was a Freemason, a politician aider, a volunteer fascist in the Spanish civil war, a writer, an entrepreneur, a firm manager and a poet too. Author has decided to examine the poems written by Gelli starting from the principle that a people can lie to journalists, investigators, politicians but not to himself when writes poems. The author has made an analysis of some poems of Licio Gelli to try to understand, beyond the events, the man Licio Gelli. Author is the first to have did such a research After a biography of Gelli the author will present the methods and results of his research, the main features of Gelli poetry, a description of some significant poems and, will try to outline the figure as a man trying, besides, links between "private "Gelli as showed by his poems and "public" Gelli as mass media and investigators have showed . 


\section{2nd International Conference on Research in SOCIAL SCIENCES and HUMANITIES}

\section{Short biography}

Licio Gelli [ 2] was born in April 21, 1919 in Pistoia, a town in Tuscany, and was son of Hector miller and of Maria Guri a housewife. Last of four brothers at eighteen Gelli volunteered in a battalion of Black Shirt ( a paramilitary fascist organization )to participate in the Spanish Civil War in aid of the nationalist troops of General Francisco Franco. In 1939 he returned to Pistoia and told about his experience of war on Ferruccio, the weekly of the local fascist federation. He then collected these writings in a book [3]. He then became an employee of the GUF (University Fascist Youth), but never attended University (at the age of 16 he was expelled from the schools of the Kingdom of Italy after having slapped a teacher).

In July 1942, as inspector of the National Fascist Party, he was charged of transporting to Italy the treasure of King Peter II of Yugoslavia, in all, 60 tons of gold bars, 2 of ancient coins, 6 million dollars, 2 million pounds. In 1947, when the treasure returned to Yugoslavia, 20 tons of gold ingots were missing: the hypothesis was made, always denied by Gelli, that he had transferred them to Argentina at the time and that part of these 20 tons would be among the precious found in the flower boxes of Villa Wanda, the country house where Gelli lived for many years.

After September 8, 1943 he joined the Italian Social Republic and consequently became a liaison officer between the Fascist government and the Third Reich. However, when it was clear Fascist and Nazi were losing war, Gelli began to collaborate also with antifascist force making a double-game, .

- On December 16, 1944 he married Wanda Vannacci (born in Pistoia Januhttps://vas.brt.it/vas/sped_det_show.htm?brtCode=1900720017264796841\&urltype=a ary 31, 1926 and died June 14, 1993) with whom he had four children,

After the Second World War, it has been hypothesized Gelli has clothed with secret services and clandestine organizations both American and Italian and Soviet but no clear evidences of this was emerged.

Gelli, after having managed without luck a bookshop became in 1956 commercial director of Permaflex in Frosinone (an Italian city few kilometers south of Rome), a company that took funds from the Cassa per il Mezzogiorno (an Italian state organization that had to ease firms wanting to develop southern part of Italy) During his direction the factory becomes a coming and going of politicians, ministers, bishops and generals. From 1948 to 1958, Gelli was driver-secretary of a Christian Democrat deputy, elected in the district of Florence-Pistoia.

Initiated to Freemasonry (1963), in a short time he climbed the main grades, until he became venerable master of the Propaganda 2 lodge (called P2); from 1970 and 1981 he managed to enroll as a member of P2 a large number of subjects holding political and administrative offices. Although in opinion of much people P2 was only a further and well-attended seat of political business, over the years P2 has been suspected of having been the center of several political plots in Italy including at least one attempt of coup.

Gelli repeatedly declared in public that he had been a close friend of the Argentine leader Juan Domingo Perón - and often said that this friendship was really important for Italy, but without ever explaining why - and many exponents of the power circle of the last 


\section{2nd International Conference on Research in SOCIAL SCIENCES and HUMANITIES}

Peronism, as well as of the Uruguayan coup in the seventies, were enrolled in his Masonic lodge.

On March 17, 1981, the investigating judges Gherardo Colombo and Giuliano Turone, as part of an investigation into the fake kidnapping of the financier Michele Sindona, searched Gelli's villa in Arezzo and his factory (the "Giole", in Castiglion Fibocchi), and this action led to the discovery of a long list of senior officers of the armed forces and public officials adhering to the P2. The list, whose existence had soon become famous thanks to the media, also included the entire executive group of the Italian secret services, parliamentarians, industrialists, journalists, senior military.

In those days, Licio Gelli escaped to Switzerland, where he was arrested, on September 13, 1982, while trying to withdraw tens of thousands of dollars in Geneva, but, on August 10, 1983, he managed to escape from prison. He then fled to South America, before establishing himself in Switzerland in 1987. The national scandal following the discovery of the lists was almost dramatic, because of many of the most delicate positions of the Italian Republic were occupied by affiliates of Gelli organization. The central court of the Grand Orient of Italy, with a sentence of 31 October 1981, decreed the expulsion of Gelli from the Masonic Order. The Italian Parliament quickly passed a law to ban secret associations in Italy and at the same time (December 1981), a parliamentary committee of inquiry was created, chaired by the deputy Tina Anselmi (DC), which closed its work in 1984. .

In the conclusions [4] of the majority report of this commission on the P2 and on Gelli, it's has written:

"The examination of the events and the links which can be established between them on the basis of the knowledge lead to two conclusions which the Commission want to submit to the Parliament for examination. The first is the extent and seriousness of the phenomenon which, at all levels of responsibility, involves the most qualified aspects of national life. In fact, we have found that the P2 Lodge has been a decisive element in financial events, as those involving people as Sindona and Calvi, which have affected the Italian economic ambient in an important way. ... The second conclusion we have reached is that in this vast and complex operation a general design of undeniable political value can be recognize a design that not only has intrinsic political value in itself but responds, in its genesis and in its ultimate aims, to objectively political criteria.

The two conclusions we have reached therefore pose a final and conclusive question: it is reasonable to ask whether there is not a disproportion between the overall operation and the character who appears to be its main interpreter. ........ We have seen how Licio Gelli has made use of a technique of instrumental approach respect to everything he has approached during his career. Instrumental is his relationship with Freemasonry, instrumental is his relationship with military environments, instrumental is his relationship with subversive environments, instrumental is the contact he establishes with men and institutions. This instrumental approach derives by a concept of political power controlling everything and responding only to itself, as opposed to the government that exercises power, but is at the same time at the service of citizens ....... This, in fact, is in the logic of its theoretical conception and its practical construction the Lodge Propaganda 2: a neutral instrument of intervention for operations of control and conditioning. “ 


\section{2nd International Conference on Research in SOCIAL SCIENCES and HUMANITIES}

. Apart from the events mentioned in the report Licio Gelli was also involved as a suspect in other serious facts. Like the Bologna massacre or the bankruptcy of Banco Ambrosiano. As a result Licio Gelli has suffered a series of convictions by the Italian judiciary by final judgment for the following offenses:

Procurement of news containing state secrets.

Calumny against the Milanese magistrates Gherardo Colombo, Giuliano Turone and Guido Viola (crime prescribed by the Supreme Court).

Calumny aggravated by the purpose of terrorism for having tried to misrepresent the investigation into the massacre at the station of Bologna, a case for which he was sentenced to 10 years.

Fraudulent bankruptcy (Banco Ambrosiano at the time the most important not state bank in Italy).

In 1992 he was sentenced for defamation against Indro Montanelli (one of the most famous Italian newspapermen):

In 1993 he was investigated for offense to the honor of the at time President of the Republic Oscar Luigi Scalfaro for an article published in the monthly Il Piave and in 1994 was sentenced to 8 months : Having had contacts with much people Licio Gelli has accumulated real archives too

On February 11, 2006 Licio Gelli donated to the State Archives of Pistoia his "not secret archive", .

The numerous archives distributed between Montevideo, Switzerland, Villa Wanda, Castiglion Fibocchi, Argentina and Montecarlo are still secret, and only available to the heirs. Gelli had continuous contacts with the Argentinean environment, having also the double citizenship.

Licio Gelli had cultivated good relations with the general and President of Argentina, Rober.T

Massera who a few days after the coup, on March 28, 1976, wrote to Gelli to express "his sincere joy at how everything had developed according to the established plans" and wish him "a strong and firm government on his positions and intentions that would be able to stifle the insurrection of the rampant movements of Marxist inspiration". Relations with the military will continue after the return of democracy in Argentina in 1983.

From 2001 until his death, Licio Gelli was in home detention in his Villa Wanda in Arezzo, where he served his 12-year sentence for the fraudulent bankruptcy of the Ambrosiano. In Arezzo, on 2 August 2006, he married Gabriela Vasile, born in Lupsa, Romania, on 17 September 1958, in his second marriage. Also in 2006 his residence Villa Wanda was seized and auctioned by the Italian State for the payment of the legal costs of the bankruptcy of Banco Ambrosiano (amounting to about 1.5 million euro), after several attempts at auction gone deserted, the property was repurchased by Gelli himself at a much lower price than the original .

. On October 10, 2013, Villa Wanda was seized because Gelli was investigated by the Arezzo Public Prosecutor's Office together with some family members for tax offenses for 17 million euro.

Licio Gelli dies in his residence at the age of 96 on 15 December 2015. Among his many activities Gelli was also a poet author of numerous books. Because of his importance many hooks have been writing [5] [6],[7],[8] on his 


\section{2nd International Conference on Research in SOCIAL SCIENCES and HUMANITIES}

The poems

The poems contained in the volume Le ultime poesie del maestro Licio Gelli (the last poem of Master Licio Gelli ) published in 2016 by A.Car press in Milan, and other poems found on the internet.[ 9] were analyzed. It's to note Gelli had written many poems books [10],[11],[12] Unless otherwise indicated, the quotations will mention the poems contained in the book cited above, poems written between 2005 and the Gelli death. The poems are with free verses without rhymes and with a variable number of syllables generally more than eleven. The structure in many cases is of seven quatrains but in some poems there is a structure in two or three parts composed of about ten verses with number of syllables less than eleven. The language is an Italian practically with no items from other languages. The words are those of the common language without lofty words. The topics treated are strictly personal, there is no explicit reference both to Italian stories and to Italian or foreign public persons Poems are reflections with a generally bitter tone of an old man who presents himself as defeated and rather bitter.

The author has looked for words in the texts that could recall the Freemasonry to which Gelli has been enrolled for decades. Words such as cousin, freemason, lodge, square, compass. No term has been found. A similar searching has been made searching for words related to investigations or trials, words such as judge, investigation, inquires, police, examination. Nothing was found. And no term was found linked to military ambient. This fact reminds that final report of the Italian Parliamentary Commission affirmed on activities of P2. In this report it is stated that Gelli adherence to Freemasonry, his contacts with military and political circles should not be seen as a result of convictions but should be seen as instrumental to the management of power and public relations activities. There is therefore a perfect correspondence between the results of the Commission investigations and the Gelli man, as can be seen from his poems.

Reading the poems carefully, there are vague hints of Gelli youth or past, but they are always negative hints. In the poem Le anonime angoscie (The Anonymous Anguishes), there is phrase peccati che nella mia gioventù mi costrinsero a trasgredire (sins which in my youth forced me to transgress). In the poem Nelle serate di Ottobre (In the evenings of October) is written La memoria di vecchie, distanti e precarie speranze riempie l ombra di questa vita ora consumata ( The memory of old, far and precarious hopes fills the shadow of this life now consumed). In the poem Pietra su pietra (Stone by stone) there is the phrase Ho sciupato i mie anni senza una vera ragione ( I wasted my years for no real reason). In the poem Aforismi di altri tempi (Aphorisms of other times) there is the phrase La mia storia è stata consumata da acerbi dolori (My story has been crowned with acerbic pains). In the poem Solo illusioni (Only illusions) contained in the book Il mio domani ( My Tomorrow) there is the phrase e una vita equivoca piena di trappole( and an equivocal life full of traps) and expressions similar to these there are in many other poems.

However, Gelli attitude towards the years of his childhood appears to be different. Gelli keeps an excellent memory and a real nostalgia for those years. In the poem Le cose 


\section{2nd International Conference on Research in SOCIAL SCIENCES and HUMANITIES}

amate (the things loved) from the book "My Tomorrow" are mentioned I soldatini di piombo, I miei quaderni di scuola, in cui io scrivevo parole per I miei primi amori che ora più non ricordo( the lead soldiers, my school notebooks in which I wrote phrases for my first loves that now I do not remember.)

It should be noted, however, that the negative judgment on his past is not accompanied by an assumption of responsibility. Gelli believes he has done well but has not achieved what he wanted and he believes that human ingratitude has not recognized his merits. In poem Un'oasi di pace (An oasis of peace) Gelli says, Ho cercato di allontanare lodio dai cuori umani inventando abbracci ed adiposi appelli alla pace (I have tried to remove hatred from human hearts by inventing hugs and fateful appeals for peace) and in poem $\mathrm{Nel}$ sibilo del vento(in the hiss of the wind) he says Ho sempre voluto assistere chi ne aveva bisogno quando nel mondo crollavano le gocce di paura ( I have always wanted to assist those in need when drops of fear collapsed in the world). We will return to these words, or similar words, because they throw an important light on what could have been the role of Gelli in Italian history.

In Gelli poems a strong almost an obsessive presence there is : :the memory and regret of his late wife Wanda Vannacci. No mention there is of his second wife.

Mrs. Wanda is remembered as the one who filled the days and lives of Gelli with love, joy, laughter that put him back in a good mood after tiring and tormented days. Turquoise eyes, laughter, runs in the garden (probably the garden of the villa owned by Gelli in Arezzo ) are remembered.

Some poems such as Occhi turchesi( (turquoise eyes) and la lunga linea azzurra (the long blue line) are explicitly dedicated to her.

The relationship with his children is very different and much more negative. The references to children are rare and very critical. In the poem Le amare ombre (the beloved shadows) there is written Le parole dure come sentenze dette dai miei discendenti contro la mia volontà ( the words hard like sentences said by my descendants against my will), in the poem Il Testamento ( the will) Gelli speaks about Indegno comportamento ( unworthy behavior) and in the poem Manciate di sorrisi ( handfuls of smiles) answering himself tells $E$ questo è forse il destino di noi genitori di crescere I loro figli e di ricevere da loro ingratitudine ( And this is perhaps the destiny of us parents to do grow up their children and then to receive their ingratitude).

Then there is a negative judgment that extends to the whole mankind . Emblematic in this regard is what Gelli writes in his poem I cancelli dell'alba (The Gates of Dawn). Gelli writes L'umanità è confusa e cerca $i$ valori del passato...la gente non sa dove va ma ha fretta di arrivare e si scruta tutto intorno senza sapere il perché hanno tutti gli occhi stanchi e umettati di pianto mentre la loro mente cerca conforto nel passato (Mankind is confused and seeks the values of the past... people do not know where they are going but they are in a hurry to get there and they look around without knowing why they have all their eyes tired and moistened with tears while their mind seeks comfort in the past). 


\section{2nd International Conference on Research in SOCIAL SCIENCES and HUMANITIES}

Last but not least, one topic of Gelli poems is faith in God, or rather in a Lord who isn't identified with any religion but it is often invoked by Gelli. The first part of the poem Nella foresta della vita (In the forest of life) present in the book Spremute al tramonto(squeezed at sunset) is a true prayer where Gelli calls upon the Lord to make him rejoice at the blossoming of flowers, to make his sadness vanish from his heart, to make him find an oasis in the morning desert, to make him discover in doubt his dormant hopes, to make him enjoy the little eyes of the Sun, to make him discover the secrets hidden in the clouds. It should be noted that a few days after his death his confessor said in last years Gelli had regained faith in God by abandoning previous secular if not atheistic positions.

In conclusion, the image given by his poems is that of a man who feels un guerriero sconfitto che mostra le sue ferite (a defeated warrior who shows his wounds) as a verse of Flebile preda del vento (Feeble prey of the wind) says. It is not surprising, therefore, that the words that connect to an idea of day and light such as day, light, clarity, sun are much fewer than those related to the dark as oxen, night, moon, evening and so on. It's to note that this " nocturne "feature of Gelli poems is fully opposed to " sunny" attitude of Giosuè Carducci poems. Remind Giosuè Carducci first Italian poet to win Nobel prize for literature was a Freemason too.

\section{Some notable poems}

Some of Gelli poems are very indicative of this poet poetics. One of these is called Ricordo di Venezia (Memories of Venice) for copyright reasons it is not possible to report the text. The important thing is this. Gelli says that the Venice he has seen and that has fascinated him is not the one that tourists see (the gondolas, St. March square, the Carnival, the St. March Cathedral, the Rialto Bridge, etc. ..) but the Venice behind the scenes full of intrigues, secret meetings, forbidden loves, revenges of betrayed lovers. A Venice full of daring escapes like Casanova escape or murders for revenge. A picture that calls to mind the mysterious events of the Italian chronicle in which Gelli was involved. It's as if Gelli is using this deadly and mysterious Venice as a metaphor to represent Italy. or at least the Italy of which he was the protagonist.

Completely different is the poem La lunga linea azzurra (long blue line ) This poem is a delicate and romantic memory of his wife. The long blue line is the horizon line of their love that tutto separa il giorno dalla notte la felcità dal dolore ( everything separates, day from night, happiness from pain ) and so on. Gelli remembers his wife as a fairy a fairy child who ran behind the butterflies in the garden while laughing and had her hair in the wind and where he found solace from his problems. It is too easy to see behind these words the regret of a quiet family life in which Gelli took refuge in the period in which he was one of the protagonists of the less clear Italian events. .

Dedicated to parents is instead the poem A mia madre e mio padre ( To my mother and my father ) in which Gelli regrets and thanks his parents. Gelli remembers his father's affection and tenderness and remembers wisdom in words in silences and actions. Gelli 


\section{2nd International Conference on Research in SOCIAL SCIENCES and HUMANITIES}

compares his father to the largest tree in a forest Poetry ends with the humpback that he will see his own in the afterlife. You can see that this poem reflects a strong and sincere affection but the image it give us of relationships and parents is an image of a traditional Italian family with the father who leads the family and works while the mother grows up children.

A singular poem is the poem Canzoni dal mare ( Songs from the sea). Gelli tells to have visited a museum of seafaring, probably the Museum of the Italian Navy of La Spezia, and to have seen a figurehead of a ship. Gelli then thinks of all the legends that concern the figureheads. Sad and dramatic legends like that of the figurehead that starts to sing and then the storm breaks out destroying the ship. Or the legend of a captain who fell in love with the figurehead as if she was a living person and went with her to crush on an iceberg Gelli was never a seaman and he was never a sailor It can be thought the figurehead as an allegory of power that fascinates and ruins those who want to reach him.

\section{Conclusions}

Concluding the first thing that is to say is that the Gelli poet appears different from the public Gelli. The public Gelli appears as an extrovert man with many friendships and acquaintances a man many engaged in maneuvers, few clear operations, conspiracies, intrigues, a man who knows a lot of people. The Gelli poet appears as a people bitter, introvert, nostalgic of his wife, who continually turns to the Lord. This contradiction can be solved by this way. We can assume that Gelli was a man of public relations, a man who made others meet, who mediated among other people. Gelli did this not because he was naturally extroverted but because this was the role he had chosen or that he found himself playing. So contacts with so many environments and important people but all, as rightly noted by the P2 committee, instrumental to achieve certain goals. Gelli appears as a real estate agent who knows many people not because he loves worldly life but because his job is selling houses and therefore he must know buyers, sellers, renters and so on. So Gelli not appeared a puppet of other powers as assumed by many nor a puppeteer but a mediator. One can ask himself if Gelli worked for the goals of others (Argentine military, Italian wanting coup, American or Western secret services ) or had his own goals.. With regard to this, it's to be noted a desire for peace, tranquility or order emerges reading the poems and this desire is well connected to his youthful adhesion to fascism. On the other hand shortly before dying Gelli would said "I have always been fascist to the core" [13] Furthermore, as we have already said the picture that Gelli gives of his ideal family is that of the traditional Italian family and his Italian can be defined "autarkic " . These are the features of a right man who wants the order and organization of society. The total absence of references to Freemasonry also confirms the framework outlined by the Commission of its relationship with Masonry purely instrumental A man joining the Freemasonry simply to have more contact with much people, not as an adherence to an ideal. So the analysis of Gelli poems leads to important conclusions about man and one can think if such an examination can be conducted on other personalities of other countries or/and of other epochs. 


\section{2nd International Conference on Research in SOCIAL SCIENCES and HUMANITIES}

\section{Reference}

[1] For information about single Italian event or single Italian personality let see the corresponding issue on wikipedia.it

[2] Information on Gelli life in wikipedia.it issue " Licio Gelli “

[3] Gelli Licio (1940) Fuoco! Cronache legionarie della insurreione antibolscevica in Spagna( Fire! Legionary chronicles of the anti-Bolshevist insurrection in Spain), Pistoia,Tipografia Coomerciale

[4] cited in Zavoli Sergio, (1992), La notte della repubblica ( The night of republic).Roma, Nuova Eri press

[5] Wilian Philip (1991) Puppet masters the political use of terrorism in Italy, London Constable

[6] Iovino Alessandro (2015), Licio Gelli il burattinaio di Italia ( Licio Gelli the puppet master of Italy) Rome, Graus press

[7] Leoressi Lucio Il potere invisibile la verità di Licio Gelli ( The invisible power the truth of Licio Gelli ), Milan, A Car press

[8] Galli Giorgio La venerabile trama la vera storia di Licio Gelli e della P2 ( the venerable plot the true history of Gelli and of P2) Rome, Lindau press

[9] from http://www.club.it/autori/licio.gelli/licio.gelli.poesie.html.

[10] Gelli Licio (2008), Diziionario poetico( Poetic dictionary), Milano, A car press

[11] Gelli Licio (1971), Luce di stelle alpine( Light of alpine stars),Milano,Sansoni press

[12] Gelli Licio (2002), Stelle filanti ( ), Bari, Laterza press

[13] http://video.espresso.repubblica.it/tutti-i-video/licio-gelli--sono-fascista-e-morirofascista/7258/7281 